\title{
Lessons learned from thickening and filtering tailings for dry stacking
}

\author{
D Connelly METS Engineering Group, Australia
}

\begin{abstract}
The metallurgical testwork for a new gold project indicated acceptable settling rates and filtration rates. The equipment was sized, and the plant constructed. Subsequently, commissioning of the thickening and filtration for dry stacking of tailings indicated serious deficiencies with the design and a much lower achievable throughput. The throughput was some 30\% of design and cash flow considerations were that the project throughput was restricted by poor performance of the thickeners and tailings filtration acting as a bottleneck.

Mineral Engineering Technical Services Pty Ltd was commissioned with the task of increasing filtration throughput and removing the bottleneck.

For the thickeners, new flocculants were evaluated, changes to the flocculant dilution were made, and thickener underflow pump speeds were increased. An additional filter feed storage tank was installed to allow for short-term filter shutdowns.

With the two belt filters, various flocculants, guar and diatomaceous earth were evaluated. Also, more permeable filter cloths were evaluated in order to increase filtration rates. The single biggest improvement achieved was with the use of coagulants.
\end{abstract}

This paper describes how the task was managed and what steps were taken to achieve design throughput.

Keywords: argillic alteration, filtering, kaolin clay, tailings stacking

\section{$1 \quad$ Introduction}

Troy Resources NL is developing the Casposo gold-silver project in Argentina. The front end of the processing plant is based on second-hand equipment from the McKinnons gold project in Cobar, New South Wales, Australia. Second-hand equipment is used wherever possible in order to achieve a financially viable project. Equipment sourced as used also has the advantage of being immediately available.

Like many resource projects, the Casposo gold-silver project was prohibited by high capital costs. The financial model developed by the previous owners assumed construction of a new processing plant. A major challenge in order to make the project a reality was to develop an innovative approach to the project to reduce the capital expenditure (CAPEX) as to improve the project's fundamental economics.

The results of the comminution testwork were used to provide an assessment of the suitability of an existing second-hand crushing and grinding circuit for the application. Simulation software (JKSimMet) was used to model the comminution circuit providing a high level of confidence. Mineral Engineering Technical Services Pty Ltd (METS) evaluated and sourced suitable second-hand equipment from multiple locations for the rest of the plant. A three-dimensional computer model of the plant was created using SolidWorks to allow proper layout of the plant and to provide a basis for generating general arrangement drawings for onsite engineering personnel.

METS developed the process design documentation for the Casposo gold-silver project for Troy Resources $\mathrm{NL}$. This included development of the process flow sheets, process design criteria, mechanical equipment list and general arrangement drawings. These documents provide a schematic overview of the equipment, consumables and utilities while illustrating the process flows of the Casposo plant design. 


\section{Project location}

The Casposo process plant, as designated by Troy Resources NL, is situated in northwestern Argentina in the San Juan Province. The site coordinates of the plant are at latitude $31^{\circ} 12^{\prime} \mathrm{S}$ and longitude $69^{\circ} 36^{\prime} \mathrm{W}$ at an average elevation of 2,400 metres above sea level (masl). Location of the project is shown in Figure 1.

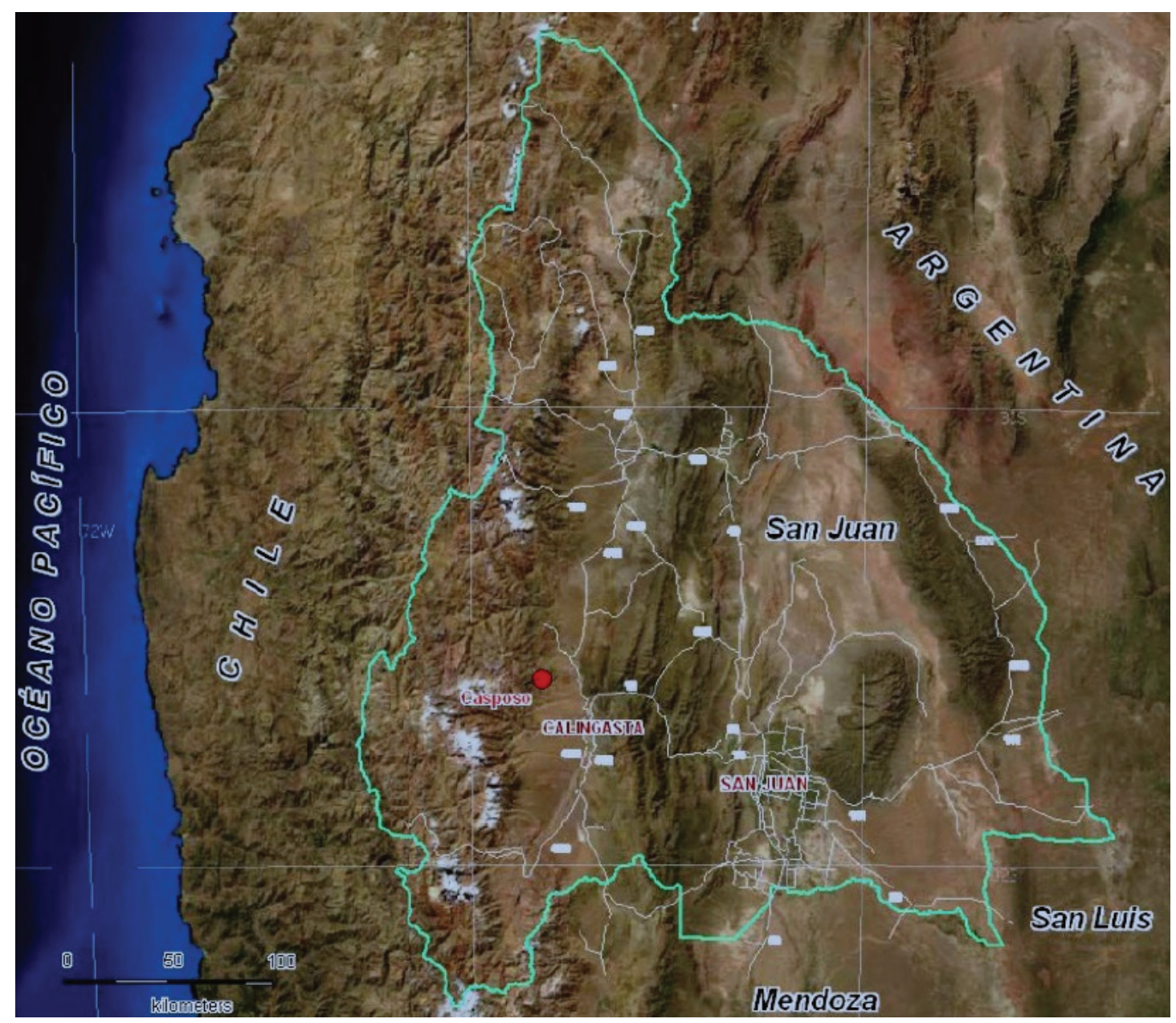

Figure 1 Casposo gold-silver project location

\section{$3 \quad$ Project geology}

The San Juan Province straddles three major north-south trending ranges; the Cordillera Principal, Cordillera Frontal, and Precordillera, as well as part of the Sierras Pampean range. The Casposo gold-silver project is located on the eastern border of the Cordillera Frontal range, separated from the Precordillera by the Rode-Calingasta-Uspallata Valley.

The Cordillera Frontal range is underlain by marine sediments (shale, sandstone and conglomerates) of the Carboniferous Cerro Aqua Negra Formation. These sedimentary materials are overlain by a thick intrusive and volcanic sequence assigned to the Permian-Triassic Choiyoi group. Basal andesitic volcanic flows, tuffs and breccias are the main sub-surface unit in the Casposo Property and are overlain by rhyolite breccias, rhyolite-dacite flows and dacitic ignimbrite flows.

Mineralisation at the project occurs along a $10 \mathrm{~km}$ long west-northwest regional structural corridor, with the main Kamila vein system forming a sigmoidal set $500 \mathrm{~m}$ long near the centre. The Mercado vein system is the northwesterly continuation of Kamila, separated by an east-west fault. The mineralisation identified at the Kamila and Mercado deposits, and other prospects within Casposo.

The gold-silver project is an example of low-sulphidation epithermal deposition of gold and silver. 
Mineralisation characteristically comprises pyrite, electrum, gold, silver, and argentite. Other minerals can include chalcopyrite, sphalerite, galena, tetrahedrite, and silver sulphosalt and/or selenide minerals. In alkalic host rocks, tellurides, roscoelite and fluorite may be abundant, with lesser molybdenite as an accessory mineral.

The gold-silver mineralisation at the Kamila deposit is structurally controlled and occurs in crustiform; colloform quartz veins and stockworks in both andesites and rhyolites. The veins extend for about $2 \mathrm{~km}$ in a northwesterly direction, attaining widths of up to $500 \mathrm{~m}$. Arsenopyrite and stibnite occur in the working zones that are developed adjacent to the quartz gold-bearing veins. Vein alteration is characterised by strong to pervasive silicification. Banded quartz-calcite veins with lattice bladed textures are common in the andesites. Interpretations of the drillcore show that mineralisation is vertically zoned.

Mineralisation within the Mercado vein system contains moderately higher base metal values, as well as increased amounts of iron and arsenic sulphides, in comparison to the Kamila deposit.

Argillic alteration was not mentioned in the core logs, and from a processing perspective, the understanding was that a hard rock quartz ore would be processed.

\section{$4 \quad$ Climatic}

The area is on the foothills of the Andes at 2,500 m elevation with a dry climate. Snowfall can occur occasionally during very cold winters.

Based on the dry climate, dry stacked tailings were selected during the feasibility study.

\section{$5 \quad$ Feasibility study}

A bankable feasibility study (BFS) for the Casposo gold-silver project was commissioned by Intrepid Mines Limited (Intrepid) in 2005 and completed by AMEC Peru S.A. (AMEC) in 2007. Some of the key findings are summarised below (Colquhoun et al. 2007).

The 2007 feasibility study (Colquhoun et al. 2007) was based on the proposed mining of two deposits: Kamila and Mercado. The Kamila deposit is larger and would be mined first. It was to be mined by open pit methods and the deeper portion by underground mining methods.

As of October 2006, the total indicated resources at the two deposits comprised $2.18 \mathrm{Mt}$ at $4.46 \mathrm{~g} / \mathrm{t} \mathrm{Au}$ and $116 \mathrm{~g} / \mathrm{t} \mathrm{Ag}$ at a cut-off grade of $1.40 \mathrm{~g} / \mathrm{t}$ gold equivalent. The cut-off grade was based on a gold price of USD $450 /$ oz.

The plant and facilities were designed for an average milling rate of 1,000 t/d (365,000 t/a). Projected overall gold and silver recoveries were 93.7 and $80.6 \%$ respectively. Over a mine life of five years, average annual production was estimated at 50,478 oz of gold and $1.1 \mathrm{Moz}$ of silver per year, over a mine life of five years.

The process flow sheet was designed to use conventional primary jaw and secondary cone crushing, ball milling, gravity concentration for coarse gold and silver, cyanide leach, counter current decantation, and washing and dewatering of tails by belt filtration. Gold and silver would be recovered by standard MerrillCrowe precipitation and smelted to produce doré bars. Tailings solids are washed and rinsed on a belt filter to remove cyanide and then filtered tailings trucked to a lined tailings storage facility for dry stacking.

Major infrastructure was required to develop the project including site roads, diesel power generation plant, fuel storage, water supply, contractor areas and administration facilities.

A new capital cost estimation of USD $120 \mathrm{M}$ was reduced to USD $45.5 \mathrm{M}$ by using second-hand equipment and owner construction. The life-of-mine total operating costs including mining, processing, general and administration were projected to be USD 47.34/t of ore milled. Financial analysis of the project suggested it was more sensitive to changes in metal price and grade than either capital or operating costs. 


\section{$6 \quad$ Metallurgical testwork}

Thorough, accurate testwork is vital to producing a viable economic project and a process which will not provide unwanted surprises once production is underway. A variety of metallurgical testwork has been undertaken on Casposo ore over the last 10 or so years. A brief summary of this work by AMEC is presented here (METS et al. 2009a).

Several exploration and drilling campaigns have also been undertaken at Casposo since 1998 in order to establish a resource estimate and map the deposit.

\subsection{Drill samples}

These were diamond drill holes and typically quartz veins with gold and silver. Argillic alteration and clays were not noted in the hard rock. With the value of hindsight these samples were not representative of what was eventually mined.

\subsection{Head assay}

A head assay performed in 2010 produced gold and silver grades of 8.9 and $157 \mathrm{~g} / \mathrm{t}$ respectively. These were in agreement with previous analyses. The high ratio of silver to gold in the ore warranted consideration for a Merrill-Crowe process option to be considered.

\subsection{Leach testwork}

A range of leach testwork performed on Casposo samples showed the leach kinetics of the gold is significantly faster than the leaching kinetics of the silver. This is likely due to the presence of significant quantities of silver sulphide minerals. The impact of this is that a longer residence time is required in order to attain acceptable silver recoveries. A longer residence time requires larger equipment volumes and, therefore, higher capital cost.

Other key results included:

- Good recoveries were achieved using oxygen/air.

- High cyanide concentration improved the leach kinetics of silver significantly, although it did not alter that of the gold.

- No benefit in recoveries with zinc addition. Zinc addition caused increased reagent consumption as zinc is a cyanide-consuming species.

- High levels of iron in solution occurred.

- Finer grinding can improve recoveries.

- The high levels of iron in solution incurred a negative impact on reagent consumption. The addition of a gravity circuit within the process can mitigate this problem.

Several tests were carried out to assess the effect of lead nitrate on the silver leaching kinetics. The lead nitrate did not significantly improve the leaching kinetics of the silver as expected.

\subsection{Settling and filtration}

Thickening testwork on the Mercado and Kamila ore samples yielded poor solution clarity.

Filtration tests were conducted on the leach residue using both flocculant and guar gum (filtration aid). The aim of these tests was to determine the impact of each on the filtration rates. Flocculant and guar added individually both reduce the cake formation time, thereby improving the filtration rate. However, the rate improved further when the flocculant and guar gum were added together. 
The SGS feasibility study settling test results (Figure 2) with and without flocculant were excellent. The overflow yielded poor clarity, but this was not a concern. This was very different to the settling behaviour during operation where high underflow densities could not be achieved and considerable work had to be undertaken to get the thickeners operational.

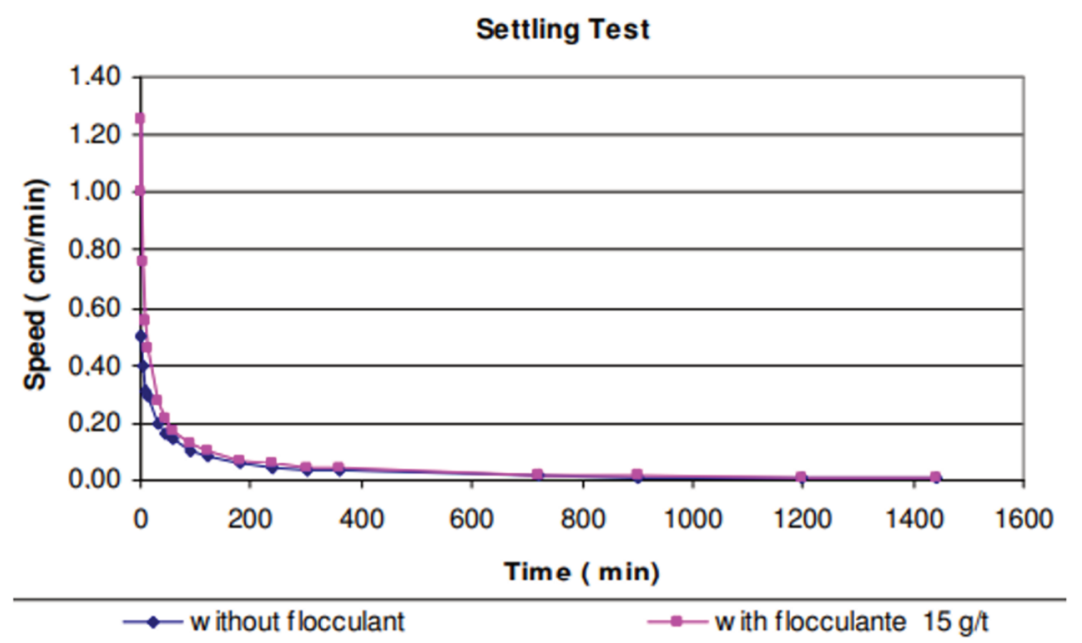

\section{Figure 2 Settling tests leach slurry}

The laboratory filtration rates from SGS testwork (Table 1) were from 82 to $622 \mathrm{k} / \mathrm{h} / \mathrm{m}^{2}$. The higher results being achieved with guar. During commissioning using guar, the filtration rates were $<10 \mathrm{~kg} / \mathrm{h} / \mathrm{m}^{2}$. It is believed the low filtration rates were due to the clays which were not present to the same extent in the feasibility testwork samples.

Table 1 Filtration test results

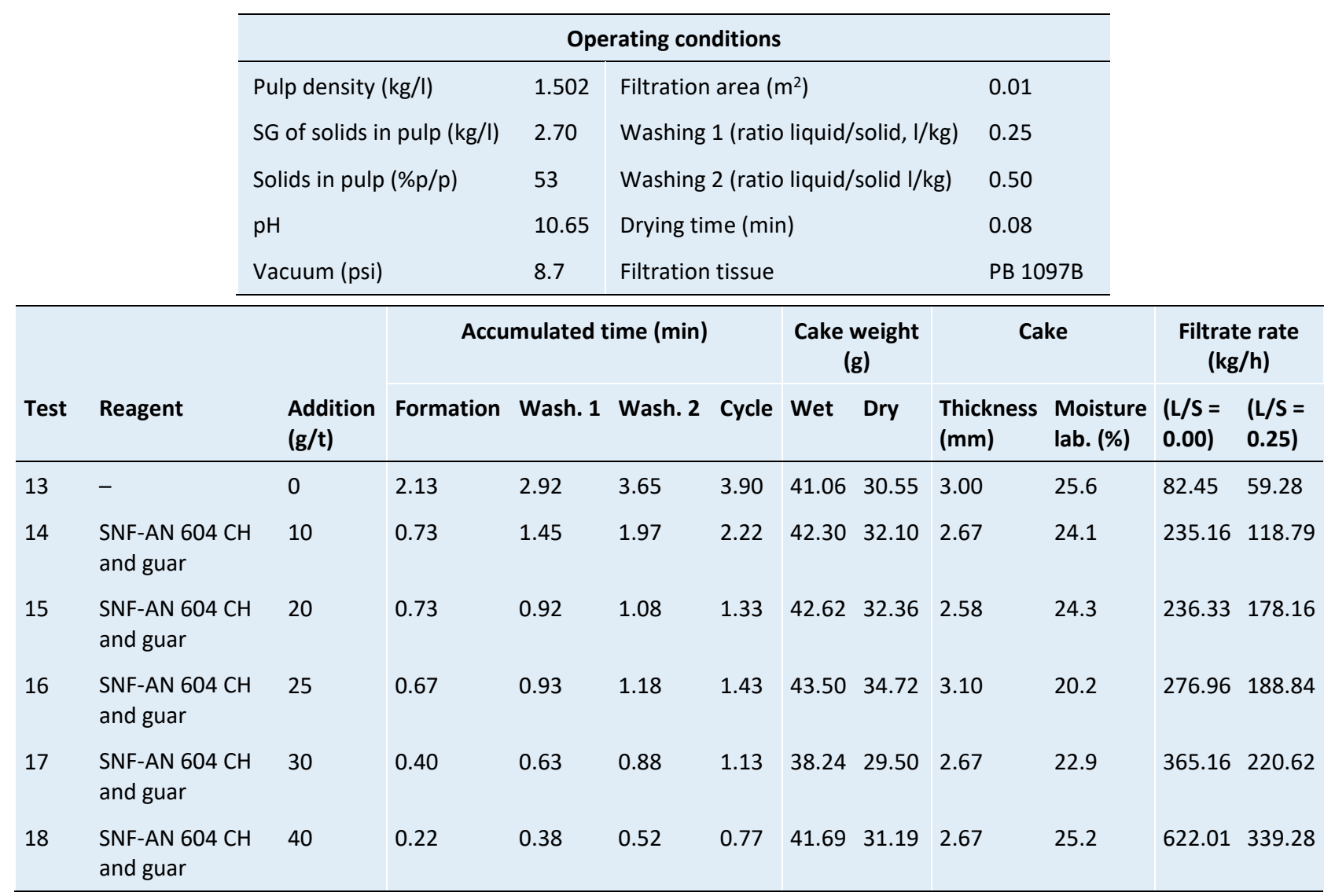

Note: Filtrate rate includes $5 \mathrm{~s}$ of drying between washings and $5 \mathrm{~s}$ after the last washing. The filter aids SNF AN 604CH and guar were used $50 \%$ each to make up a mixture of additives for these tests. 


\subsection{Zinc dust cementation (Merrill-Crowe Process)}

Some operating data is available in the literature including reagent addition rates and solution quality requirements. However, some key process parameters such as the influence of zinc dust particle size on the reaction kinetics are not well understood. Further tests were conducted looking at different zinc dust particle sizes. Finer zinc dust accelerates the reaction kinetics. However, if too fine a product is used it may impact on the filter press cycle times by blinding the filter press cloths.

\subsection{Cyanide destruction}

The cyanide destruction process (INCO process) is important in maintaining a low level of cyanide in the tailings as required by the environmental authorities. The INCO SO $\mathrm{S}_{2}$ /air cyanide destruction process was investigated. This uses a combination of $\mathrm{SO}_{2}$ and $\mathrm{O}_{2}$, in the presence of soluble copper, to oxidise cyanide. Both free cyanide (CN) and cyanide weakly complexed with metals such as copper, zinc and nickel are oxidised to form cyanate ions $\left(\mathrm{OCN}^{-}\right)$, which are less toxic by two orders of magnitude. During the process, the ferro-cyanide complexes are removed as insoluble ferro-cyanide salts. In addition, a small amount of thiocyanate $(\mathrm{SCN})$ is oxidised.

Continuous tests were conducted to determine what levels of free cyanide could be achieved. The kinetics of the reaction depends on the oxidising conditions. In a highly oxidising environment, it is expected that the reactions would proceed quickly. A key measure for the oxidising conditions is the ratio of the mass of $\mathrm{SO}_{2}$ to that of the weak-acid-dissociated CN. Testwork suggested this ratio should be maintained above three.

\section{$7 \quad$ Flow sheet}

The Casposo processing plant will handle up to 438,000 tpa of ore. At 8,000 working hours per annum, this is equivalent to $55 \mathrm{tph}$. The crushing section will operate at a higher rate than the rest of the plant to allow for reduced operating hours and equipment maintenance. Thus, the crushing plant is designed to operate at a feed rate of up to 110 tph (METS et al. 2010b).

Crushed ore entering the grinding circuit is fed into the SAG mill feed chute together with recycled grinding circuit water. It is added at a rate to maintain a mill discharge density of up to $65 \%$ solids by weight. The SAG mill operates with a ball charge up to $5 \%$ by volume. Mill scats report to the scats crusher, and then crushed scats are fed back to the SAG mill feed belt.

Slurry from the SAG mill is fed to a cluster of six $250 \mathrm{~mm}$ hydrocyclones. The majority of the cyclone underflow returns to the mill and cyclone overflow flows to the leach feed thickener.

A split stream from the cyclone underflow feeds the gravity circuit screen. The gravity circuit screen oversize is combined with the gravity concentrator tailings and returned to the SAG mill discharge hopper.

The gravity concentrator processes the screen undersize. This concentrator retains a gravity concentrate and produces a gravity tail. The gravity tail is returned to the comminution circuit via the SAG mill discharge hopper for further liberation. When the gravity concentrate becomes sufficiently enriched, it is transferred to the intensive leach reactor (ILR) for leaching under intensive conditions.

The ILR is a specialist precious metals leach unit that uses alkaline cyanide solution to leach gold and metallic silver from the high-grade gravity concentrates. The concentrates are collected in the concentrate feed tank. When sufficient concentrate has been collected, the batch is transferred to a horizontal rotating drum together with barren solution and hydrogen peroxide. Cyanide solution, caustic solution and lead nitrate solution are added to the reactor. The pregnant solution is then pumped to join other streams entering the Clarification area to remove any solids and recover the gold and silver. 
Thickened cyclone overflow slurry is pumped to the leach tanks. There are nine agitated leach tanks linked in series. The total volume of the tanks is designed for up to 80 hours of leach residence time depending on the leach throughput. Due to the slow leaching kinetics of silver, an elevated cyanide concentration needs to be maintained in each of the leach tanks. Cyanide solution is added to leach tank 1 to achieve a nominal concentration of 2,200 ppm and ensure a sufficient cyanide concentration is maintained throughout the leach train.

The leach slurry feeds the first counter current decantation (CCD) thickener where the solids settle to the underflow for pumping to the second CCD thickener. The final underflow from the second CCD thickener is filtered using the belt filters.

Two tailings belt filters operate in parallel to produce a filter cake of $<14 \%$ moisture for tailings disposal at a nominal rate of $46 \mathrm{dt} / \mathrm{h}$ and a maximum rate of $55 \mathrm{dt} / \mathrm{h}$.

The overflow from CCD thickener 1 is pumped from the CCD thickener overflow tank into the pre-clarification hopper. The Merrill-Crowe process requires low levels of solids, $<1 \mathrm{ppm}$, to be effective. The solution from the CCD and filtration area is clarified to achieve the target solids content. The pre-clarification hopper removes fine solids carried over from the thickeners by forming a bed of flocs through which the dirty solution is passed upwards. Following deaeration, the clean, oxygen-free pregnant solution is mixed with zinc dust, in the form of slurry, to recover the gold and silver by cementation.

\subsection{Merrill-Crowe}

The Merrill-Crowe process was discussed briefly above. The key reasons for the selection of this process by AMEC was that the silver to gold ratio in the Casposo ore was about 24 to one, meaning it is not economical to process using either carbon in pulp (CIP) or carbon in leach (CIL) methods, due to the high amount of carbon required for stripping. The Merrill-Crowe process was included in the Casposo process flow sheet to reduce carbon usage, thus reducing the stripping cost. The processing plant is shown in Figure 3.

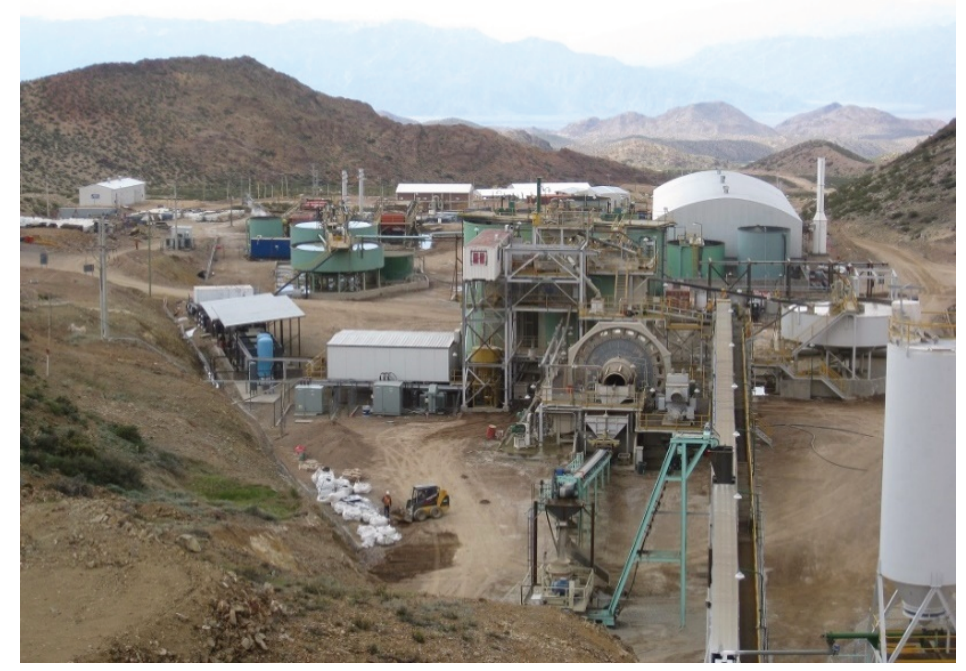

Figure 3 Casposo gold-silver plant 


\section{$8 \quad$ Tailings}

The filtered tailings were conveyed out to a dry stacked tailings dam. The tailings were placed on high-density polyethylene which allowed drainage of any liquor into a pond that could be pumped back to the process water (Figures 4 and 5).

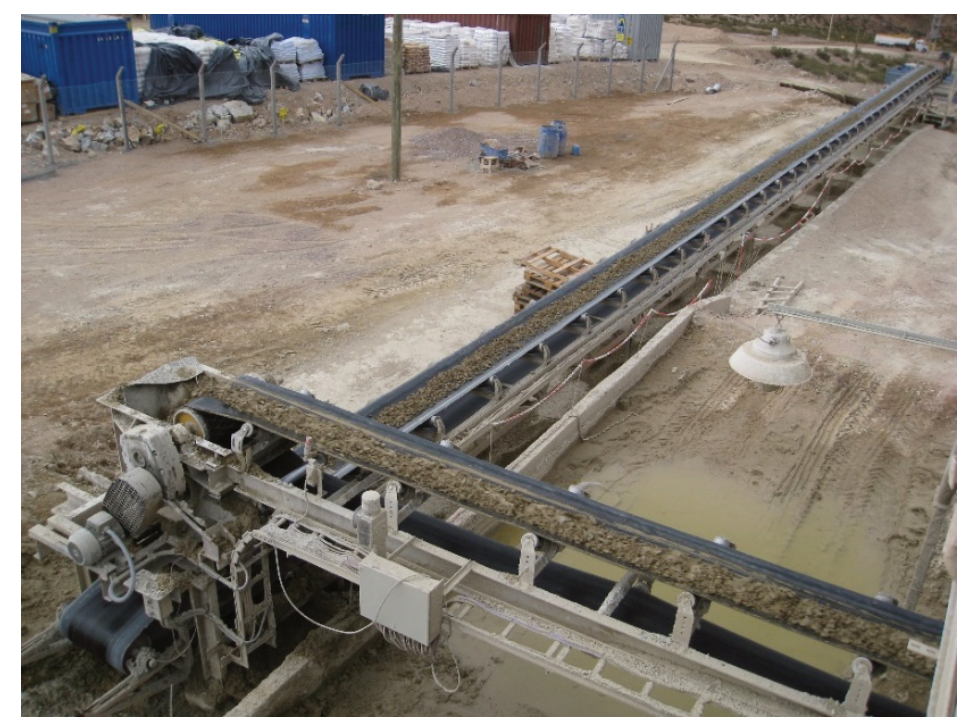

Figure 4 Conveyed tailings filter cake

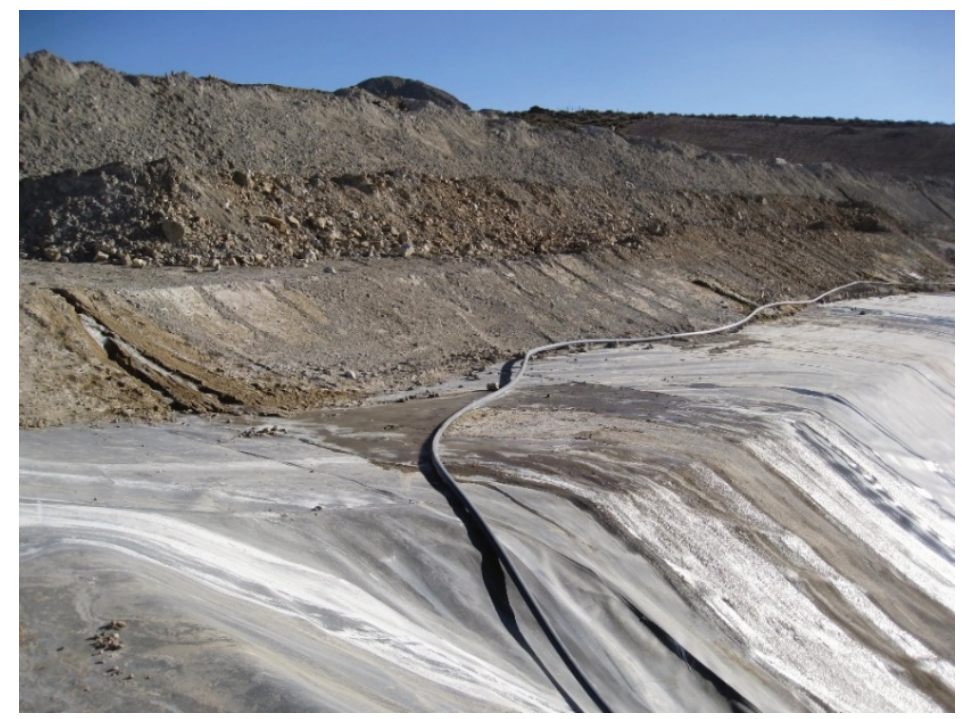

Figure 5 Dry stacked tailings

\section{$9 \quad$ Commissioning issues and lessons learned}

The original sample selection was flawed, and the samples were not representative of what was processed from the open pit. The presence of clays was deemed a major issue upon commissioning and preventative measures could have been taken to anticipate the variability and processing amenability (Figure 6).

A major lesson from the successful completion of this project was the importance of modelling to clarify and confirm the suitability of the second-hand equipment. The JKSimMet process modelling confirmed that the crushing and grinding plant would be suitable, but that the scats crusher would be a necessary addition (METS et al. 2009b). 


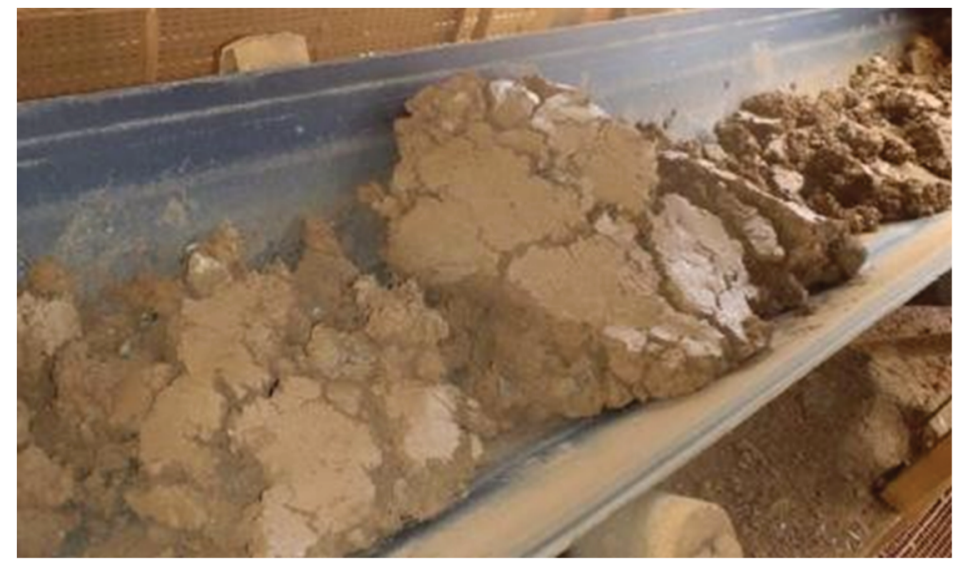

\section{Figure 6 Ore feed to SAG mill}

Hydrothermal alteration results from the interaction of hot waters with rocks to form clay minerals. This is not uncommon in epithermal deposits and results in clays persisting at depths which would not be expected.

The phenomena of hard quartz rock with interspersed clay ( 5 to $15 \%$ clay) as a result of hydrothermal fluids is quite deceptive with regards to how the rock will process (Figure 7).

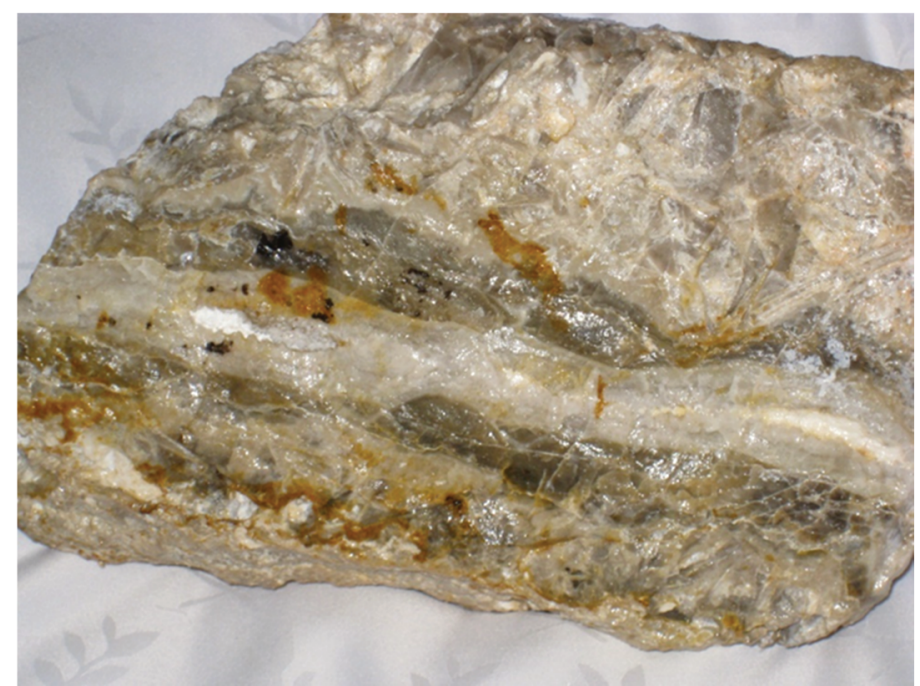

Figure 7 Argilic alteration of hard rock ore containing kaolin bands

This clay was not discovered in the metallurgical testwork. Once commissioning started, the ore exhibited settling issues and the tailings with clay was characterised by poor filtration rates as seen in Figure 8 .

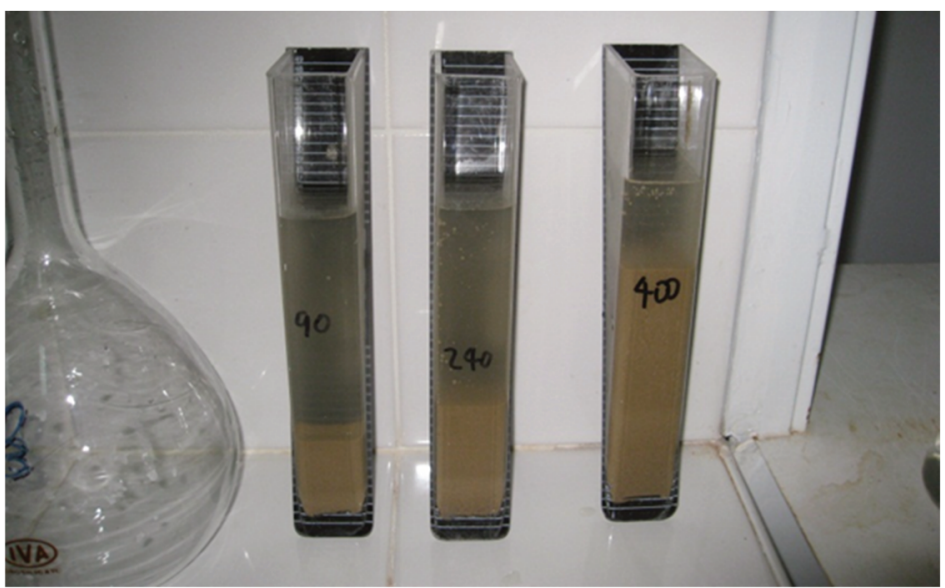

Figure 8 Thickener overflow testing with clarity wedges 


\section{$9.1 \quad$ Thickening}

Merrill-Crowe is not as user friendly as CIP. Settling and clarity of overflow solutions is paramount in successful solution processing and precipitating gold. The use of tailings filtering is subject to feed variability due to different ore characteristics. For example, filtration rates can be affected by weathered ore (low) versus fresh free quartz veins (high).

The flocculant selected from original testwork proved poor after several months of operating due to salt build-up and chemistry changes of the process water. Screening onsite found a superior flocculant which was ordered immediately. Simultaneously, the underflow pumps had a pulley change to allow for increased speeds and improve CCD mass flow. A revisit of the basic design and using actual settling rates in the plant highlighted the thickeners were undersized. Also, instead of four CCD thickeners, two were specified with belt filters. To accommodate, at least three or four larger thickeners should have been included in the design, see Figure 9.

Water management is also critical, particularly when part of the process is taken offline.

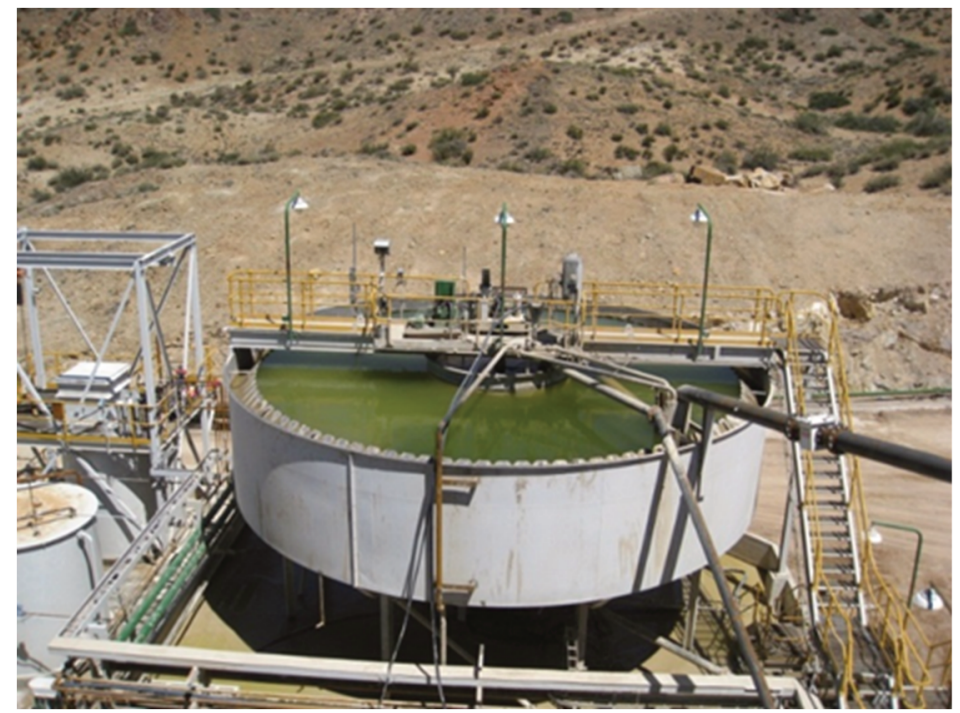

Figure 9 The undersized Casposo $12 \mathrm{~m}$ thickeners

Thickening of clays is difficult due to the fine particles ( $<2$ microns) which are highly charged surfaces. This requires flocculant screening and optimisation of the $\mathrm{pH}$ to achieve acceptable settling rates. The overflows can be dirty which may cause problems with downstream processing. Additionally, the presence of clays affects the ultimate underflow density and the choice of underflow pumps (positive displacement, not centrifugal pumps). The design had assumed $60 \%$ solids $\mathrm{w} / \mathrm{w}$ in the underflow, whereas realistically $50 \%$ solids $w / w$ was typically achieved.

The dirty thickener overflow overloaded the pre-clarifier and reduced the cycle time on the clarifier filters. This meant more frequent stoppages to clean the cloths with a high pressure Gerni gun. Furthermore, it was necessary to investigate optimisation of the pre-clarifier which was too small for the loading. Further work was undertaken to investigate more permeable filter cloths.

\subsection{Filtering issues}

The two belt filters were bottlenecking the facility operating at $25 \%$ of design because of the clays. Tenova (Delkor) and others were consulted but the throughput was not improved. METS investigated flocculants and guar, but no improvement in throughput was achieved. A second filter feed tank was installed because the filter availability assumed was much higher than actual. Diatomaceous earth was used on the belt filters and this improved filtering. The next major improvement was the screening work that identified coagulants to 
reduce cake formation time and aid the filtration rate. Design throughput was achieved but the filter cake moisture was much higher than originally designed (Figure 10) (METS et al. 2010a).

The design moisture was $10 \%$, however , the actual moisture with the clays was up to $30 \% \mathrm{w} / \mathrm{w}$. This increased moisture meant the tailings were stuck, and blockages at transfer points were common. This necessitated more operators to watch for blockages and clear them when they occurred. This resulted in increased drainage from the dry stacked tailings.

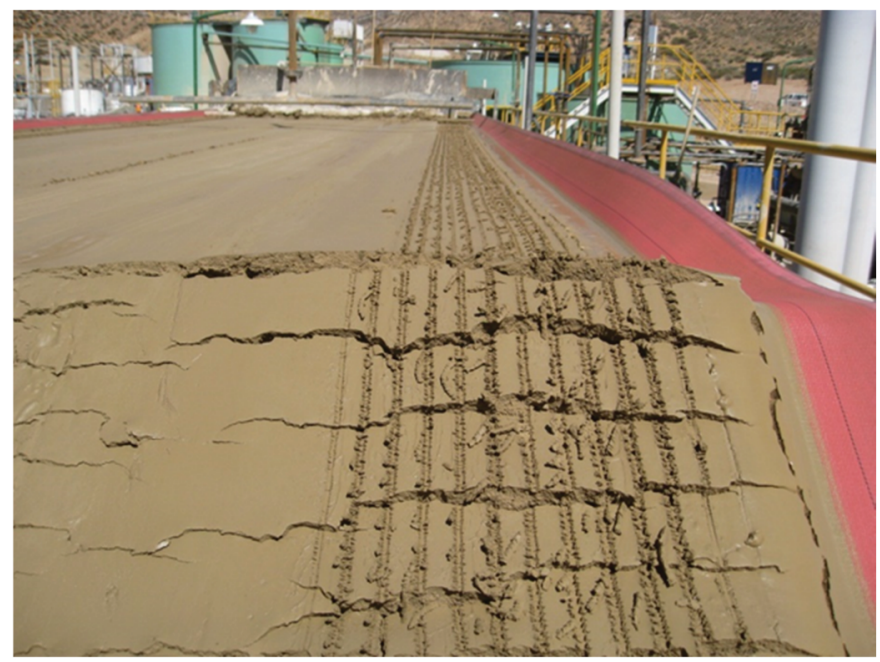

Figure 10 Belt filter discharge cake

\subsection{Second-hand plant}

The need to consider innovative and 'outside-the-box' solutions is also highlighted by the success of this project. A reduction in half the capital cost by utilising a pre-owned facility was imperative in the development of the project. Selecting the Merrill-Crowe route over CIP or CIL processes was another. Few projects consider these options; however, they are often able to help bridge the gap to commercial feasibility.

\subsection{Lessons learned}

The original feasibility study testwork indicated high settling and filtration rates would be achieved. The actual performance came as a complete surprise and delayed ramp up. The samples tested were not representative when compared to the low filtration rates achieved during operation and optimisation required for the thickeners.

Pressure filters will always provide higher performance than vacuum filters.

The nature of the clay and the volume percentage in the feed impacts adversely on filtration rates, clarity of filtrate, spillage and maintenance issues.

Filter aids can significantly improve filtration rates. Generally, higher $\mathrm{pH}$, coagulants, guar and ensuing combinations result in reduced water recovery. Prior laboratory testing before plant trials is required.

The presence of clays causes excess spillage with clays adhering to cloths requiring washing and excess maintenance.

\section{Conclusion}

The wet filtered tails drained requiring collecting the drain liquor and pumping this back to the process water. The height of stacked tailings was also limited because of the wet tailings and the risk of slumping. A realistic tailings moisture would have been $10 \%$; however, the tailings were typically $30 \%$ moisture because of the clays. 
The SAG mill application has been more successful than predicted, achieving higher throughputs and better grinds than predicted. The ore has shown to be more variable than was anticipated from the drilling, core logging and geological interpretation.

Merrill-Crowe is not as straightforward as the CIP process and although there are several disadvantages with the process, for high silver ores there are generally not many viable alternatives.

Managing the water balance presents challenges, as does weathered ore when it comes to settling and filtering. The importance of clean solutions for processing and precipitation is also a challenge if the ore is not fresh. New technology such as resins and EMEW ${ }^{\circledR}$ cells will be considered now that the project is operational and the technical risks of such technology can be managed.

The concept of minimal engineering (i.e. project management of a group of sub-consultants to execute the project) did result in substantial savings in time and money.

The use of whole dry stacked tailings filtration was dictated by the seismicity and sensitive environmental area of the project location, meaning a conventional tailings dam is impractical.

The project impact has been very positive for Troy Resources NL and the local community. Exploration in the region has resulted in the discovery of new resources and the operation's future may continue beyond the present resources.

Understanding the geology, mineralogy and correctly selecting representative samples of the ore to be processed is critical in achieving an efficient metallurgical process.

Clays have the potential, if not recognised, to destroy project economics. Testwork with representative ore samples at an early stage of project development is critical.

The presence of clays in hard rock comes as a surprise if not fully understood. Similarly, waste dilution from country rock containing clay can adversely affect the process. There are some solutions which assist in processing ores but will generally not negate all the difficulties.

The presence of clays has a major influence on the process selection and equipment used in the final flow sheet. The industry has paid a heavy price on several projects where the clay was not recognised, or the process plant was based on a hard rock design which later proved unsuitable for processing and detrimental to the project.

Attempting to mitigate the impact of clay on the process if the percentage of clay in the feed cannot be controlled can be highly difficult to manage in mineral processing plants.

\section{Acknowledgement}

The authors thank Troy Resources NL for permission to publish this paper, and all colleagues and engineers at various sites, METS staff and other consultants for their contribution, and the management of METS for their permission and constructive criticism of various drafts of this paper.

\section{References}

Colquhoun, W, Taylor, G, Marinho, RM \& Simon, A 2007, Casposo Project Technical Report on Feasibility Study, unpublished report to Intrepid Minerals Corporation.

METS 2009a, Casposo Gold-Silver Project: Previous Metallurgical Testwork Summary, unpublished report to Troy Resources NL, Mineral Engineering Technical Services Pty Ltd.

METS 2009b, Casposo Milling Circuit Simulation Report, unpublished report to Troy Resources NL, Mineral Engineering Technical Services Pty Ltd.

METS 2010a, Casposo Gold-Silver project: Metallurgical Testwork Summary Report, unpublished report to Troy Resources NL, Mineral Engineering Technical Services Pty Ltd.

METS 2010b, Casposo Gold-Silver project: Process Description, unpublished report to Troy Resources NL, Mineral Engineering Technical Services Pty Ltd. 